\section{PERFORMANCE OF RADIAL POINT INTERPOLATION METHOD IN SOLVING KINEMATIC WAVE EQUATION FOR HYDROLOGIC MODELLING}

H. Hirola*, M. A. Mohd Noora, M. Z. Abd Jamila, M. H. Mokhtarama,b, E. H. Kasimana, A. Y. Mohd Yassinc

aSchool of Civil Engineering, Universiti Teknologi Malaysia, 81310 UTM Johor Bahru, Johor, Malaysia

bDepartment of Civil Engineering, Universiti Selangor, 45600, Bestari Jaya, Selangor, Malaysia

cSchool of Energy, Geoscience, Infrastructure and Society, HeriotWatt University Malaysia, 62200, Putrajaya, Malaysia
Article history

Received

31 July 2019

Received in revised form

3 March 2020

Accepted

9 March 2020

Published online

23 April 2020

*Corresponding author halinawati@utm.my

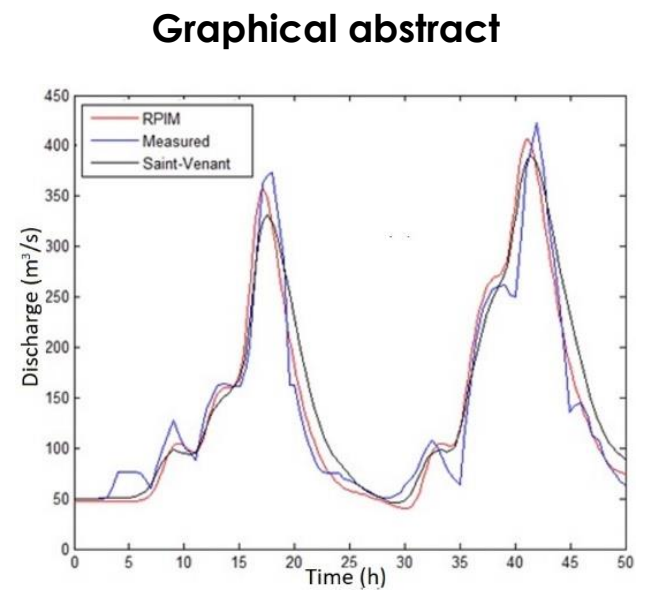

Keywords: Meshless method, radial point interpolation method, saint venant kinematic wave, hydrologic modeling, finite element method, finite difference method

\begin{abstract}
Abstrak
Kertas kerja ini membentangkan penyelesaian persamaan gelombang kinematik dengan menggunakan kaedah Interpolasi Titik Radial Tanpa Mesh (RPIM). Persamaan pembezaan separa dibincangkan dengan menggunakan kaedah pemberat residual Galerkin yang menggunakan fungsi bentuk RPIM. Skema perbezaan hadapan digunakan untuk pengantian sementara manakala kaedah penggantian langsung digunakan untuk menyelesaikan sistem tak linear pada setiap langkah masa. Perumusan ini disahkan dengan membuat perbandingan denga penyelesaian dari teknik numerik konvensional dan pemerhatian fizikal. Dalam semua kes, keputusan yang sangat baik dicapai dan dengan itu menjadi pengesahan kepada rumusan yang dicadangkan. Nilai optimum parameter bentuk multi-quadric kemudian ditentukan sebelum penilaian prestasi kaedah tersebut. Berdasarkan kadar konvergensi, telah ditunjukkan bahawa kaedah yang dicadangkan
\end{abstract}


melakukan lebih baik daripada kaedah perbezaan terhingga dan setara dengan kaedah unsur terhingga. Ini menonjolkan potensi RPIM sebagai kaedah alternatif untuk pemodelan hidrologi.

Kata kunci: Kaedah meshless, kaedah interpolasi titik radial, saint venant kinematik, pemodelan hidrologi, kaedah unsur terhingga, kaedah perbezaan hujung

(C) 2020 Penerbit UTM Press. All rights reserved

\subsection{INTRODUCTION}

A combination of one-dimensional continuity and momentum equations, also known as Saint Venant equations are a set of nonlinear unsteady partial differential equations. These equations are typically used in the hydrological modelling of surface runoff and channel flow. The full Saint Venant equations, commonly known as the dynamic wave equations, are often used to obtain the complete description of the flow. However, in most cases, where no backwater effect is expected and when the bed and frictional slope can be assumed as similar, the momentum equation can be simplified and represented by the Manning equation. The combination of continuity and Manning equations yields what is known as Kinematic Wave equation.

While dynamic wave equation provides better description of the flow, the numerical solutions are expensive and usually unstable. Therefore, unless necessary, the kinematic wave has been the preferred method to solve many hydrological related problems [1]. However, despite its simplicity, the equation is still unsteady and nonlinear in nature. Due to the nonlinearity, an exact solution of the equations is difficult to be obtained. Nevertheless, a limited number of exact solutions for simplified cases are available in [2-5]. For other cases, the kinematic wave equation is typically solved numerically using finite difference method (FDM) [6] or finite element method (FEM) [7, 8].

\subsection{Radial Point Interpolation Method (RPIM): A Meshless Method}

A typical numerical method such as FDM or FEM requires the construction of grid or mesh to represent the physical domain of the problem. In most engineering problems where the physical domain is complex, geometrical meshing is difficult and a time consuming process. Meshless methods are some recent attempts to remedy this shortcoming as it requires no meshing of the domain $[9,10]$.

RPIM can be considered as an enhancement of an earlier method known as Point Interpolation Method (PIM). The latter is a meshless method that uses polynomial functions to approximate the field variables. The application of PIM in hydrological modelling of flood routing has been detailed in Hirol,
(2016) and Hirol, et. al. (2017) [11, 12]. The use of PIM might lead to matrix singularity during the derivation of the shape functions due to the inappropriate choice of polynomial function, leading to an illconditioned matrix.

Alternatively, instead of polynomial function, a radial basis function can be used as an interpolation functions, the latter becomes the basis for RPIM. Liu and Gu (1999) [13] is the first to propose RPIM and the method has since been extended in [14-16]. Unlike PIM, RPIM is free from ill-conditioned matrix and singularity problem [17, 18]. The delta function property is also preserved in RPIM allowing boundary conditions to be imposed conveniently. These attractive features of RPIM motivate extension of the method to solve kinematic wave equation for hydrologic modelling.

\subsection{METHODOLOGY}

\section{Governing Equations}

Saint Venant equations [19] are time dependent partial differential equations which describe the distribution of flow rate, $Q$ and flow cross-sectional area, $A$ as functions of distance, $x$ along the channel and time $t$. The equations can be given as:

Equation of Mass

$\frac{\partial A}{d t}+\frac{\partial Q}{\partial x}=q(x)$

where $A$ is the cross-sectional area of the flow, $Q$ is the flow rate and $q(x)$ is the forcing term (i.e. precipitation, lateral flow).

Equation of Momentum

$\frac{1}{A} \frac{\partial Q}{\partial t}+\frac{1}{A} \frac{\partial}{\partial x}\left(\frac{Q^{2}}{A}\right)+g \frac{\partial y}{\partial x}-g\left(S_{o}-S_{f}\right)=0$

Where $S_{0}$ is the bed slope and $S_{f}$ is the frictional slope, whilst $y$ and $g$ are the depth of water and gravitational pull, respectively. The complete form of Equation (2) is termed as full dynamics equation. However, Equation (2) can be further simplified if it is assumed that $S_{o}=S_{f}$. This is known as the kinematic 
wave assumption. This condition can be equivalently expressed in Manning form as

$A=\alpha Q^{\beta}$

Equation (1) and (3) are the Saint Venant kinematic wave equations. By combining Equation (1) and Equation (3), the following equation can be obtained.

$\frac{\partial Q}{\partial t}+\frac{1}{\alpha \beta} Q^{(1-\beta)} \frac{\partial Q}{\partial x}=q$

\section{Weak Form of the Kinematic Wave Equation}

The kinematic wave equation given by Equation (4) can be solved numerically by converting the equation into weak form. This can be done by employing Galerkin weighted residual method. We first discretize Equation (4) in time by forwarddifference to obtain

$\frac{Q^{t+1}-Q^{t}}{\Delta t}+\frac{1}{\alpha \beta} Q^{(1-\beta), t+1} \frac{\partial Q^{t+1}}{\partial x}=q^{t+1}$

where $t+1$ and $t$ refer to present and previous timestep, respectively. Rearranging gives

$Q^{t+1}+\frac{\Delta t}{\alpha \beta} Q^{(1-\beta), t+1} \frac{\partial Q^{t+1}}{\partial x}-Q^{t}=q^{t+1}$

By weighting Equation (6) using shape functions, $N_{i}$ and expressing the flow rate as $Q=N_{j} \hat{Q}_{j}$ where $\hat{Q}_{j}$ are the nodal values of $Q$, the following is obtained.

$$
\begin{aligned}
\int_{L} N_{i}\left(N_{j} \hat{Q}_{j}+\frac{\Delta t}{\alpha \beta}\right. & N_{k} \hat{Q}_{k}{ }^{(1-\beta)} \frac{\partial N_{j} \hat{Q}_{j}}{\partial x} \\
& \left.-N_{j} \hat{Q}_{j}{ }^{t}\right) d x=\int_{L} N_{i} q d x
\end{aligned}
$$

To note, in Equation (7), superscript $t+1$ is omitted for ease of notation. By collecting the nodal values, $\hat{Q}_{j}$ and shifting known terms to the right hand side of the equation, Equation (7) can now be given as

$\left(\int_{L} N_{i} N_{j} d x+\right.$

$\left.\int_{L} \frac{\Delta t}{\alpha \beta} N_{i}\left(N_{k} \hat{Q}_{k}\right)^{(1-\beta)} \frac{\partial N_{j}}{\partial x} d x\right) \hat{Q}_{j}=$

$\int_{L} N_{i} N_{j} \hat{Q}_{j}{ }^{t} d x+\int_{L} N_{i} q d x$

Equation (8) can be represented in matrix form as

$[M+K(\hat{Q})]\{\hat{Q}\}=-\{F\}$

where $[K]$ is the coefficient matrix, $[M]$ is the mass matrix whilst $\{\hat{Q}\}$ and $\{F\}$ are the vector of nodal values and nodal loads, respectively.

\section{Nonlinear Solver}

Equation (9) is nonlinear thus requires a nonlinear solver. In this work, direct substitution scheme is employed. For mild nonlinearity the scheme works well.

\section{Derivation of RPIM Shape Functions}

RPIM interpolation function contains both radial and polynomials basis given as

$$
Q=\{R\}\{a\}^{T}+\{P\}\{b\}^{T}
$$

where $\{R\}$ is the vector of radial basis function (RBF). $\{a\}$ and $\{b\}$ are the vectors of the coefficient of RBF and the monomials, $\{P\}$ respectively. There are several forms of radial basis functions that can be used as detailed in [16]. This study uses multi-quadrics (MQ) interpolation which, for one-dimensional problem can be given as

$\{R\}=\left(\{r\}^{2}+\left(\alpha_{c} d_{c}\right)^{2}\right)^{q}$

where $\alpha_{c}$ and $q$ are the shape parameters which values can be obtained through numerical test whilst $\{r\}$ is the vector of radial distance of point of interest, $X$ pi given as

$$
\{r\}=\sqrt{\left(x-x_{p i}\right)^{2}}
$$

Coefficients in $\{a\}$ and $\{b\}$ of Equation (10) are constants which values can be determined by forcing the interpolation to be equal to nodal value of the field variable at the node's location. In evaluated form, this can be given as

$$
\{\hat{Q}\}^{T}=\left[\left.R\right|_{n}\right]\{a\}^{T}+\left[\left.P\right|_{n}\right]^{T}\{b\}^{T}
$$

where $\{\hat{Q}\}$ is the vector of the nodal values of the flow rate. $\left[\left.R\right|_{n}\right]$ and $\left[\left.P\right|_{n}\right]$ contain the evaluated values of radial basis function and the monomials evaluated at the location of the nodes respectively. Due to the additional polynomial terms, the simultaneous equation of Equation (13) can be expanded into

$$
\left\{\begin{array}{c}
\hat{Q} \\
0
\end{array}\right\}^{T}=\left[\begin{array}{cc}
\left.R\right|_{n} & \left.P\right|_{n} ^{T} \\
\left.P\right|_{n} & 0
\end{array}\right]\left\{\begin{array}{ll}
a & b
\end{array}\right\}^{T}=\left[\begin{array}{ll}
\left.G\right|_{n}
\end{array}\right]\left\{\begin{array}{ll}
a & b
\end{array}\right\}^{T}
$$

where 
$\left\{\begin{array}{c}\hat{Q} \\ 0\end{array}\right\}=\left\{\begin{array}{lllllll}\hat{Q}_{1} & \hat{Q}_{2} & \ldots & \hat{Q}_{n} & 0 & \ldots & 0\end{array}\right\}$

$\left\{\begin{array}{l}a \\ b\end{array}\right\}$

$=\left\{\begin{array}{llllllll}a_{1} & a_{2} & \ldots & a_{n} & b_{1} & b_{2} & \ldots & b_{m}\end{array}\right\}$

$\left[\left.G\right|_{n}\right]$ is termed as moment matrix. $n$ is the number of the field node in the support domain and $m$ is the number of polynomial terms used which can be zero or $m \ll n$. Using Equation (14), we can solve the corresponding coefficients as

$\left\{\begin{array}{ll}a & b\end{array}\right\}^{T}=\left[\left.G\right|_{n}\right]^{-1}\left\{\begin{array}{c}\hat{Q} \\ 0\end{array}\right\}^{T}$

By inserting Equation (17) into Equation (10) we obtain

$Q=\left\{\begin{array}{ll}R & P\end{array}\right\}\left[\left.G\right|_{n}\right]^{-1}\left\{\begin{array}{l}\hat{Q} \\ 0\end{array}\right\}^{T}$

In the same time, the flow rate can also be expressed in terms of shape functions and nodal values as

$Q=\{N\}\{\hat{Q}\}^{T}$

Since Equation (18) and Equation (19) represent the same distribution of the flow rate, evaluating the equations at a point of interest, $X_{p i}$ would give

$\left\{\left.N\right|_{p i}\right\}\{\hat{Q}\}^{T}=\left\{\left.\left.R\right|_{p i} \quad P\right|_{p i}\right\}\left[\left.G\right|_{n}\right]^{-1}\left\{\begin{array}{l}\hat{Q} \\ 0\end{array}\right\}^{T}$

After rearrangement, Equation (20) can be given as

$\left[\left.G\right|_{n}\right]^{T}\left\{\left.N\right|_{p i}\right\}^{T}=\left\{\left.\left.R\right|_{p i} \quad P\right|_{p i}\right\}^{T}$

From Equation (21), shape functions of RPIM at a point of interest i.e. $\left\{\left.N\right|_{p i}\right\}$ can be solved by employing simultaneous solver such as Gauss elimination thus avoiding the need for direct inversion.

Derivation of the First Derivative of RPIM Shape Functions

Differentiating Equation (10) and Equation (19) and evaluating at a point of interest, $X_{p i}$, give

$$
\begin{aligned}
& \left\{\begin{array}{ccc}
\left.\frac{\partial N_{1}}{\partial x}\right|_{p i} & \ldots & \left.\frac{\partial N_{n}}{\partial x}\right|_{p i}
\end{array}\right\}\left\{\begin{array}{c}
\hat{Q}_{1} \\
\hat{Q}_{2} \\
\vdots \\
\hat{Q}_{n}
\end{array}\right\}
\end{aligned}
$$

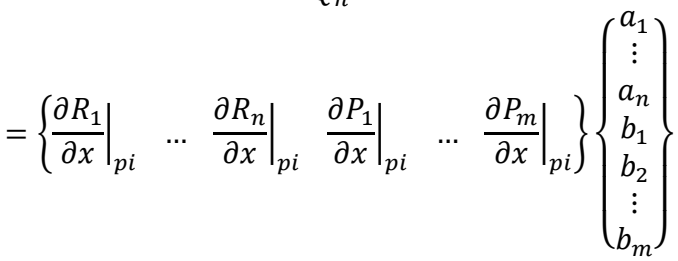

Equation (22) can be compactly expressed as

$\left\{\frac{\left.\partial N\right|_{p i}}{\partial x}\right\}\{\hat{Q}\}^{T}=\left\{\begin{array}{ll}\frac{\left.\partial R\right|_{p i}}{\partial x} & \frac{\left.\partial P\right|_{p i}}{\partial x}\end{array}\right\}\left\{\begin{array}{ll}a & b\end{array}\right\}^{T}$

Inserting Equation (14) into Equation (23) gives

$\left\{\frac{\left.\partial N\right|_{p i}}{\partial x}\right\}\left[\left.G\right|_{n}\right]\{a b\}^{T}=\left\{\frac{\left.\partial R\right|_{p i}}{\partial x} \frac{\left.\partial P\right|_{p i}}{\partial x}\right\}\{a b\}^{T}$

After some cancellations and rearrangement, we obtain

$\left[\left.G\right|_{n}\right]^{T}\left\{\frac{\left.\partial N\right|_{p i}}{\partial x}\right\}^{T}=\left\{\frac{\left.\partial R\right|_{p i}}{\partial x} \frac{\left.\partial P\right|_{p i}}{\partial x}\right\}^{T}$

By solving $\left\{\frac{\left.\partial N\right|_{p i}}{\partial x}\right\}$, we then obtain the evaluated values of the derivative of the RPIM shape functions at the point of interest.

\section{Final Form of Kinematic Wave for RPIM Formulation}

Inserting $\left\{\left.N\right|_{p i}\right\}$ of Equation(21) and $\left\{\frac{\left.\partial N\right|_{p i}}{\partial x}\right\}$ of Equation (25) into the discretized weak formulation of Equation (8), the final form of the RPIM formulation for the kinematic wave can be given as (in numerical integration forms)

$$
\begin{aligned}
& {[M]=M_{i j}=\left.\left.\sum_{f=1}^{B C} \sum_{g=1}^{G P} \widehat{W}_{g} N_{i}\right|_{g} N_{j}\right|_{g}\left|J_{f}\right|} \\
& {[K]=K_{i j}} \\
& =\left.\sum_{f=1}^{B C} \sum_{g=1}^{G P} \widehat{W}_{g} \frac{\Delta t}{\alpha \beta} N_{i}\right|_{g}\left(\left.\left.N_{k}\right|_{g} Q_{k}\right|_{g}\right)^{(1-\beta)} \frac{\left.\partial N_{j}\right|_{g}}{\partial x}\left|J_{f}\right| \\
& \{F\}=F_{i}=\sum_{f=1}^{B C} \sum_{g=1}^{G P} \widehat{W}_{g}\left[\left.\left.N_{i}\right|_{g} N_{j}\right|_{g} Q_{j}+\left.N_{i}\right|_{g} q\right]\left|J_{f}\right| \\
& {[T]=T_{i j}} \\
& =\sum_{f=1}^{B C} \sum_{g=1}^{G P} \widehat{W}_{g}\left[\left.\left.N_{i}\right|_{g} N_{j}\right|_{g}\right. \\
& \left.+\left.(2-\beta) \frac{\Delta t}{\alpha \beta} N_{i}\right|_{g}\left(\left.\left.N_{k}\right|_{g} Q_{k}\right|_{g}\right)^{(1-\beta), r-1} \frac{\left.\partial N_{j}\right|_{g}}{\partial x}\right]\left|J_{f}\right|
\end{aligned}
$$

where $\left|J_{f}\right|$ is the Jacobian for fth background cell and $\widehat{W}_{g}$ is the Gauss weighting factor for the gth Gauss point. GP is the total number of Gauss points 
and $B C$ is the background cell of the Gauss quadrature.

\subsection{RESULTS AND DISCUSSION}

Prior to the determination of the optimum value of the shape parameters of the radial basis function, the derived formulation is verified herein against two of benchmark cases.

Case 1: Verification against Chow et.al (1988) [6]

The first verification is made against the numerical solution obtained from FDM as detailed in [6]. The flow is driven by a time-varying inflow as given in Table 1. The hypothetical channel, discretized into a finite grid system, is shown in Figure 1. The channel has a bed slope of one percent and a Manning's roughness factor of 0.035 . There is no lateral flow or rainfall. The initial condition is a uniform flow of 2000 cfs along the channel.

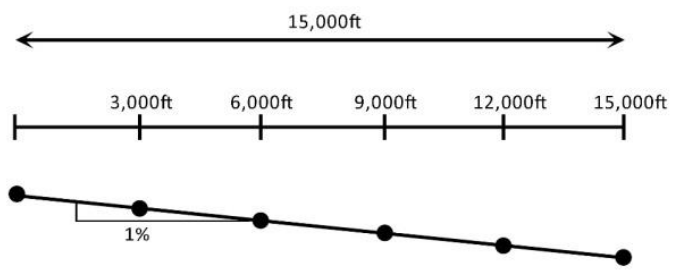

Figure 1 Uniform discretization of the channel [6]

Table 1 Inlet data [6]

\begin{tabular}{|l|l|}
\hline \multicolumn{1}{|c|}{ Inflow Time (min) } & Inflow Rate (cfs) \\
\hline 0 & 2000 \\
12 & 2000 \\
24 & 3000 \\
36 & 4000 \\
48 & 5000 \\
60 & 6000 \\
72 & 5000 \\
84 & 4000 \\
96 & 3000 \\
108 & 2000 \\
120 & 2000 \\
\hline
\end{tabular}

Figure 2 (a) shows the plot of flow rate, $Q$ calculated at various locations whilst Figure 2 (b) shows the plot of $\mathrm{Q}$ a distance of $6000 \mathrm{ft}$ from upstream. In the latter, close agreement can be observed between the results given by RPIM and and the one given by Chow (1988). It can also be seen that the RPIM solution converges with the increase in the number of node.

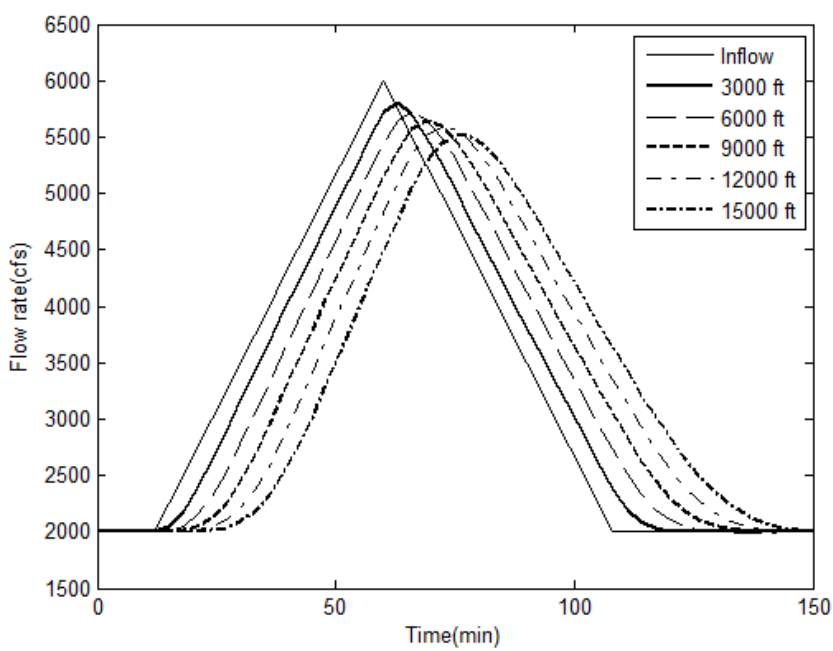

(a)

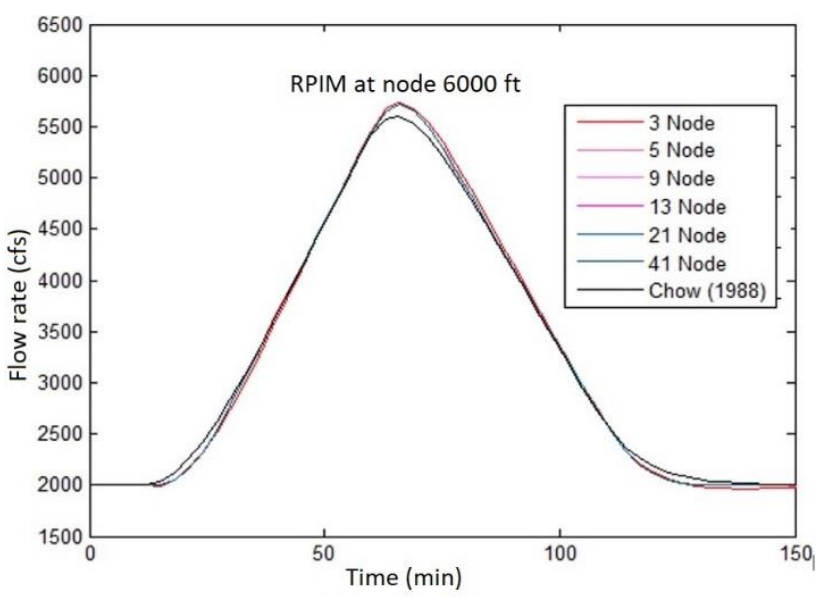

(b)

Figure 2 Flow rate validation for Case 1

Case 2: Verification against gauged (real) data (Litrico et al. 2010) [8]

In contrast to the previous case, Litrico et al. (2010) [8] dealt with real data, gauged from Jacui River in Brazil. The flow was driven by time-varying upstream boundary conditions (varying inflow) as shown in Figure 3. The data consisted of propagation of dam release on the Jacui River in Brazil between Itauba and Volta Grande, recorded at a time step of 30 minutes. Table 2 gives the data for the river. 


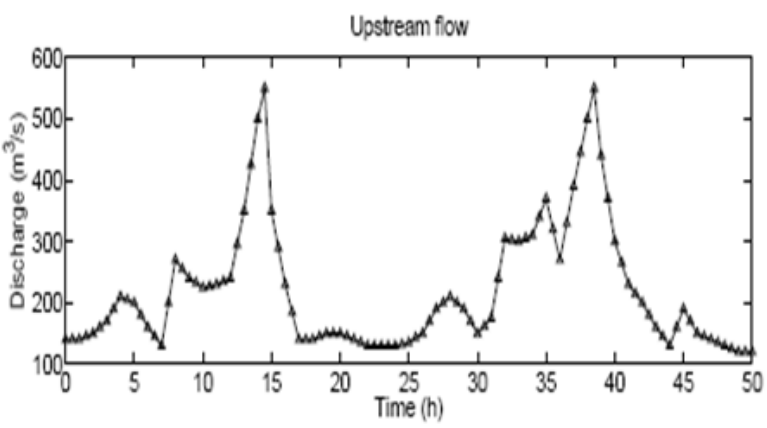

Figure 3 Upstream flow [8]

Table 2 Data of Jacui River [8]

\begin{tabular}{|l|l|}
\hline Data & Value \\
\hline Channel Length $(\mathrm{L})$ & $29600 \mathrm{~m}$ \\
\hline Width (W) & $55.6 \mathrm{~m}$ \\
\hline Manning coefficient $(\mathrm{n})$ & 0.07 \\
\hline Slope (Sb) & 0.00089 \\
\hline
\end{tabular}

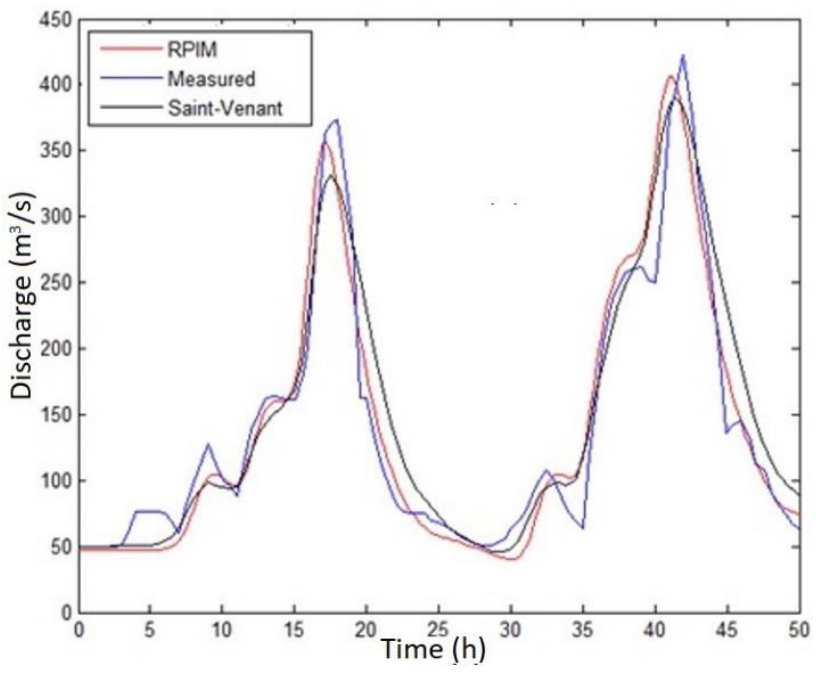

Figure 4 Flow rate validation for Case 2

Figure 4 shows the plot of the flow rates where a similar trend of prediction is given by both numerical methods plotted against the gauged data. The agreement herein (and in the previous case) validate our proposed RPIM formulation. The slight discrepancy is due to the use of arbitrary value of shape parameters in RPIM. In the next section, the optimum value of the shape parameters will be determined and then used in the convergence study.

Numerical Test to Determine the Optimum Values of Shape Parameters

Selection of shape parameters value to be used in the analysis is crucial as it governs the performance and the accuracy of a formulation [20]. By adopting
Multi-quadrics (MQ) as the radial basis function, the specification of two shape parameters, $\alpha_{c}$ and $q$ is required which values are best determined by conducting a numerical test. Optimum values are taken as those that provide the lowest error norms which can be calculated as

$$
\text { L2-norm error, } e=\frac{1}{N} \sum_{j}^{N} \frac{/ Q\left(x_{j}\right)^{R P I M}-Q\left(x_{j}\right)^{F E M} /}{\mid Q\left(x_{j}\right)^{F E M} /}
$$

where $N$ is the number of results considered whilst $Q\left(x_{j}\right)^{R P I M}$ and $Q\left(x_{j}\right)^{F E M}$ are the values of flow rates obtained from RPIM and FEM respectively. Equation (30) is a L2-norm loss function formulation. To note, since there is no closed-form solution available for the two benchmark cases, the "accurate" solution herein, i.e $Q\left(x_{j}\right)^{F E M}$ is taken as the converged value from FEM formulation.

Since there are two parameters to be determined, one is set constant at a time. Herein, the optimum value of $q$ is first sought by setting the value of $\alpha_{c}$ to unity. Figure 5 shows the error norms of the flow rates from the benchmark cases for varying values of shape parameter $q$ and numbers of nodes (i.e. 11, 21 and 41). From the plots, while the results seem to be insensitive to $q$ for Case 1, there is a slight reduction in the error norms for Case 2. Narrowing the range of the reduction in between 0.6 and 0.8 , the optimum value for $q$ is chosen as 0.7 .

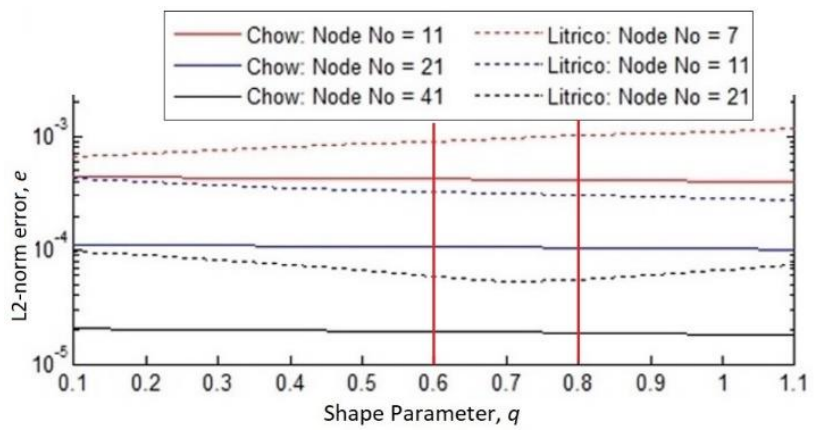

Figure 5 Optimum value determination for shape parameter $q$

Having determined the optimum value of $q$, the optimum value for $\alpha_{c}$, is then determined. Similar trend is observed where there is a slight reduction in error norms for Case 2 as shown in Figure 6. Narrowing the range of the reduction in between 0.5 and 1.5, the optimum value for $\alpha_{c}$ is chosen as unity. 


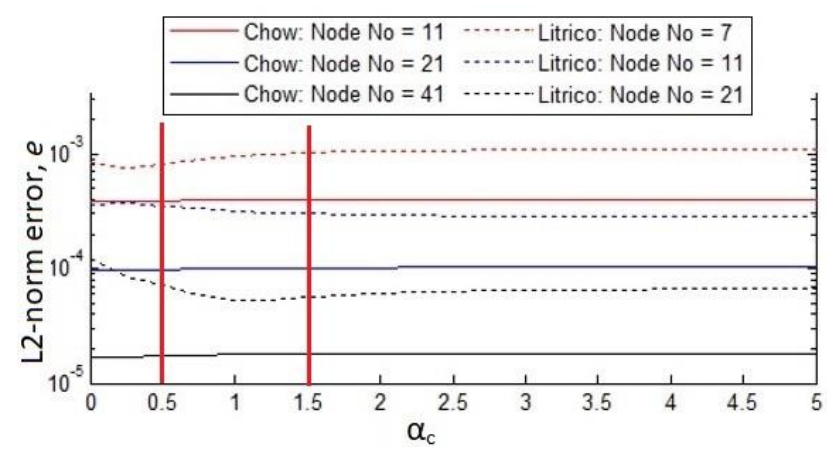

Figure 6 Optimum value determination for the shape parameter $\alpha_{c}$

Convergence Study and Assessment on the Numerical Performance

In numerical formulation related works, convergence study is an important stage as it allows the assessment of the performance of a newly derived formulation. The performance is measured in terms of the convergence rate; the rate at which the solution approaches the "correct" solution. Herein, the numerical performance of RPIM is assessed by comparing its convergence rate against FEM and FDM. To ensure that RPIM performs at its best, optimum values from previous tests are used.

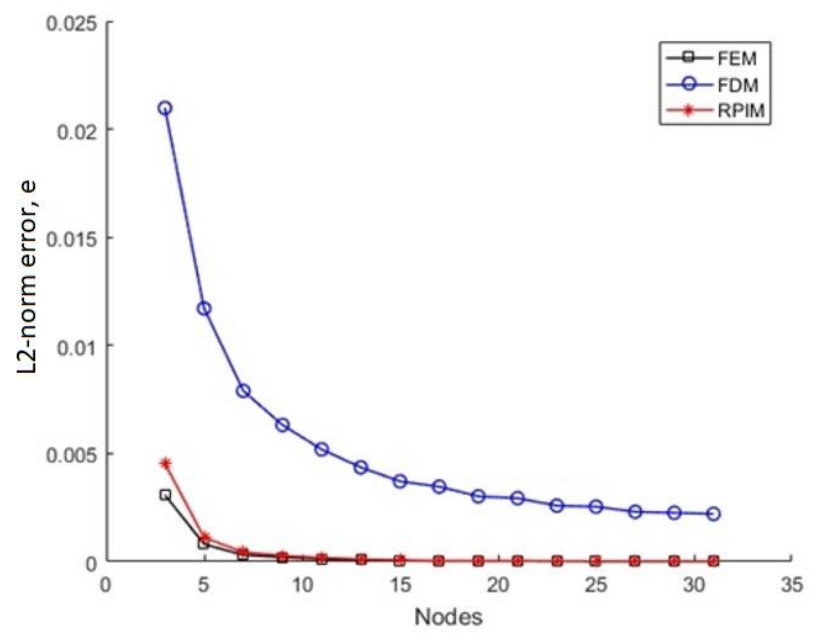

Figure 7 Convergence rate for Case 1

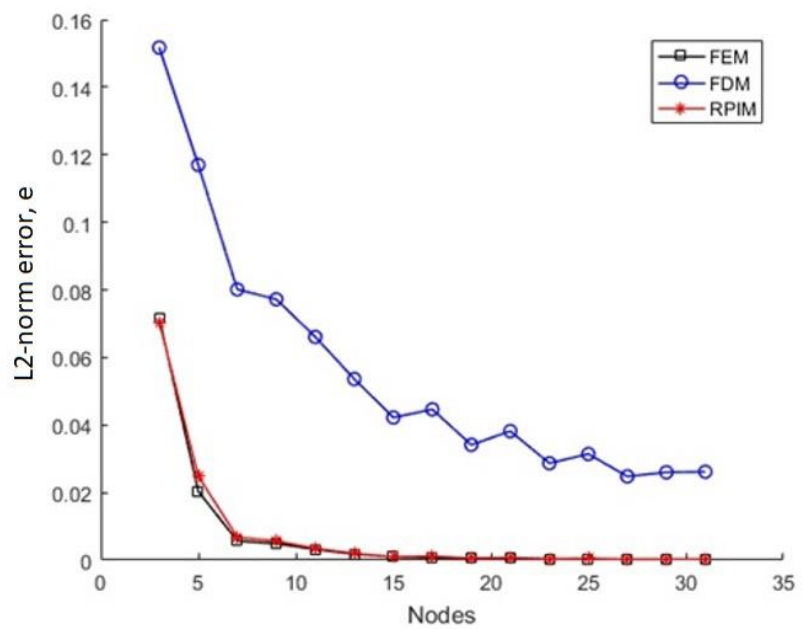

Figure 8 Convergence rate for Case 2

By referring to Figures 7 and 8, the different performance between the weighted-residual based formulations (FEM and RPIM) and the collocationbased FDM is apparent where the formers converge faster than the latter despite all being of 1st order accuracy. It is well known that the averaging of the error inherent in the weighted residual formulation would lead to a better performance. In this context, RPIM performs identical to FEM and better than FDM. This highlights the potential of RPIM as an alternative numerical method to FEM for hydrologic modelling as the method, whilst has equal performance, does not require the formation of mesh and assembly process.

\subsection{CONCLUSION}

This paper details the RPIM formulation in solving Saint Venant Kinematic Wave equation. The formulation is verified against a couple of benchmark problems. For best performance, the optimum value of the shape parameters is determined through a numerical test. Employing the optimum values, the performance of the RPIM formulation is assessed against the conventional FEM and FDM in a convergence study. It is shown that RPIM performs similar to FEM and better than FDM. This highlights the potential of the RPIM as an alternative numerical method for hydrologic modelling as it does not require the formation of mesh and assembly process. 


\section{References}

[1] Singh, V. P. 2003. Kinematic Wave Modeling in Hydrology. Bridges. 10(40685): 165.

https://doi.org/10.1061/40685(2003) 165.

[2] Hielmfelt, A. T. 1981. Overland Flow from Time-distributed Rainfall. Journal of the Hydraulics Division. 107(2): 227238.

[3] Parlange, J. Y., Rose, C. W., \& Sander, G. 1981. Kinematic Flow Approximation of Runoff on a Plane: An Exact Analytical Solution. Journal of Hydrology. 52(1): 171-176. https://doi.org/10.1016/0022-1694(81)90104-9.

[4] Govindaraju, R. S., Jones, S. E., \& Kavvas, M. L. 1988. On the Diffusion Wave Model for Overland Flow: 1. Solution for Steep Slopes. Water Resources Research. 24(5): 734744.

https://doi.org/10.1029/WR024i005p00734.

[5] Govindaraju, R. S., Kavvas, M. L., \& Jones, S. E. 1990. Approximate Analytical Solutions for Overland Flows. Water Resources Research. 26(12): 2903-2912. https://doi.org/10.1029/WR026i012p02903.

[6] Chow, V. T., Maidment, D. R., \& Mays, L. W. 1988. Applied Hydrology. New York: McGraw-Hill. 572.

[7] Vieux, B. E., Bralts, V. F., Segerlind, L. J., \& Wallace, R. B. 1990. Finite Element Watershed Modeling: Onedimensional Elements. Journal of Water Resources Planning and Management. 116(6): 803-819. https://doi.org/10.1061/(ASCE)0733-9496(1990) 1 16:6(803)

[8] Litrico, X., Pomet, J. B., \& Guinot, V. 2010. Simplified Nonlinear Modeling of River Flow Routing. Advances in Water Resources. 33(9): 1015-1023. https://doi.org/10.1016/j.advwatres.2010.06.004

[9] Liu, G. R. 2002. Meshfree Methods: Moving Beyond the Finite Element Method. Taylor \& Francis. https://doi.org/10.1201/9781420040586.

[10] Liu, G. R., \& Gu, Y. T. 2005. An Introduction to Meshfree Methods and Their Programming. Springer Science \& Business Media.

[11] Hirol, H. 2016. Meshfree Formulations of Kinematic Wave for Channel Flow Routing. Ph.D. Universiti Teknologi Malaysia, Malaysia.
[12] Hirol, H., Mohd Noor, M. A., Kasiman, E. H., Hong, A. K. B., Yusop, Z., and Mohd Yassin, A. Y. 2017. Meshless Point Interpolation Formulation of the Kinematic Wave Equation for Flood Routing. Journal of Engineering and Applied Sciences. 12(20): 5286-5293.

[13] Liu, G. R. \& GU, Y. T. 1999. A Point Interpolation Method. Proc. 4th Asia-Pacific Conference on Computational Mechanics, December, Singapore. 1009-1014.

[14] Liu, G. R., \& GU, Y. T. 2003. A Matrix Triangularization Algorithm for the Polynomial Point Interpolation Method. Computer Methods in Applied Mechanics and Engineering. 192(19): 2269-2295. https://doi.org/10.1016/S0045-7825(03)00266-4.

[15] Liu, G. R., \& GU, Y. T. 2004. Boundary Meshfree Methods Based on the Boundary Point Interpolation Methods. Engineering Analysis with Boundary Elements. 28(5): 475487. https://doi.org/10.1016/S0955-7997(03)00101-2.

[16] Liu, G. R., Gu, Y. T. \& Dai, K. Y. 2004. Assessment and Applications of Point Interpolation Methods for Computational Mechanics. International Journal for Numerical Methods in Engineering. 59(10): 1373-1397. https://doi.org/10.1002/nme.925.

[17] Wendland, H. 1995. Piecewise Polynomial, Positive Definite and Compactly Supported Radial Functions of Minimal Degree. Advances in Computational Mathematics. 4(1): 389-396.

https://doi.org/10.1007/BF02123482.

[18] Wendland, H. 1998. Error Estimates for Interpolation by Compactly Supported Radial Basis Functions of Minimal Degree. Journal Of Approximation Theory. 93(2): 258272. https://doi.org/10.1006/jath.1997.3137.

[19] Saint-Venant, B. D. 1871. Theory of Unsteady Water Flows, with Application to River Floods and to the Propagation of Tides in River Channels. French Academy of Science. 73(1871): 237-240.

[20] Liu, G. R., \& GU, Y. T. 2005. An Introduction to Meshfree Methods and Their Programming. Springer Science \& Business Media. 